\title{
Effects of Maize Silage Feeding on Growth Performance, Carcass Characteristics, Digestive System Weight, Chemical Composition and Meat Quality of Domestic Geese
}

Ergin Ozturk ( $\sim$ eozturk@omu.edu.tr)

Ondokuz Mayis Üniversity Agricul tural Fakulty https://orcid.org/0000-0002-6266-1117

Resul Aslan

Ondokuz Mayıs Üniversitesi: Ondokuz Mayis Universitesi

\section{Research Article}

Keywords: Goose, Fodder, Performance, Digestive system, Meat quality, Meat composition

Posted Date: January 24th, 2022

DOI: https://doi.org/10.21203/rs.3.rs-1219522/v1

License: (c) (7) This work is licensed under a Creative Commons Attribution 4.0 International License. Read Full License 


\section{Abstract}

Unlike other poultry species, geese can benefit from roughage to some extent due to the histomorphology and physicochemical characteristics of their digestive systems. The narrowing of goose habitats due to agriculture and other reasons emphasizes the provision of a food chain in the protection of the goose population. During the winter months, the supply of roughage becomes very difficult and the cost of goose diets increases. The research was carried out to determine the possibilities for geese to spend the winter season more economically by adding roughage instead of some of the concentrated feed. Therefore, in this study, corn silage was substituted at the level of $10 \%$ (S10), $20 \%$ (S20), 30\% (S30) and 40\% (S40) corn soy-based mixed feed (control group: S00). The experiment was carried out in local Turkish goose variety male geese at the age of 19 weeks (for 12 weeks) in the winter season. The result showed that substitution of corn silage instead of concentrated feed at 30 weeks did not adversely affect the investigated parameters (growth performance, carcass characteristics and yield, edible internal organ weights, digestive system length and weight, chemical composition of meat, physical and organoleptic quality characteristics). On the other hand, it was determined that it affected meat quality (hardness etc.) positively. It concluded that corn silage can be used up to $40 \%$ of the mixed feed, especially in winter feeding where roughage is not sufficiently supplied. Thus, it can be said that by using roughage instead of a portion of concentrated feed in goose diets, feed cost savings can be achieved and geese can be produced more economically.

\section{Introduction}

Geese are popular with their meat, eggs, oil, feathers, weed control, alarm, aesthetic beauties and are also grown for hobby purposes. However, goose production is not popular and they are produced in an extensive or semi-intensive system, which is generally associated with feed costs (Kuzniacka et al. 2020). Extensive family business is common in Turkey, similar to countries such as China (94.9\%), Poland, Egypt and Hungary, which lead the world in goose production (2.5 million tons) (FAO, 2016; Abou-Kassem et al. 2019). Goose meat is a beneficial and healthy food due to its high quality protein, low cholesterol $(52-76 \mathrm{mg} / 100 \mathrm{~g})$ and high concentrations of polyunsaturated fatty acids (PUFA) (Liu and Zhou, 2013; Cui et al. 2015; Wang, 2017; Boz et al. 2019; Tang et al. 2020; Haraf et al. 2021).

Geese can digest fibrous feeds at a higher rate (15-30\%) because they have a well-developed caeca and large intestine that provide microbial fragmentation, and a well-muscled gizzard that can develop a pressure around twice that of chickens and even ducks (Zhang et al. 2013; Li et al. 2019; 2020; Yan et al. 2019). Therefore, geese can easily fit into sustainable farming systems when combined with their ability to utilize high-fiber forage from the many green plant species in pastures and meadows, their ability to forage and their aquatic nature. These special physiological digestive features of the geese allow the use of fiber, which can be called excellent, and the use of green roughage in their diets instead of some of the concentrated feeds (Zhang et al. 2013; Kokoszynski, 2014; Li et al. 2017; Song et al. 2017; Li et al. 2017) and other inexpensive products (Arslan, 2013). However, elucidating the genes and gene network regulation mechanisms (Tang et al. 2020) that underlie the growth and development of the still unknown geese may contribute significantly to the more economical production of goose meat.

In addition, it is known that in many countries, there are no habitats where geese can graze all the time, or that there are difficulties in supplying green fodder, especially in winter, and arid climates regions (Clausen et al. 2018; Uher-Koch et al. 2021). In cases where the pasture conditions do not meet the need, green fodder that has been cut and finely chopped can be used or artificial pastures can be created with a mixture of grasses and legumes (Clausen et al. 2018). Considering the low digestibility of corn silage in geese during the winter months, it has been stated that it can be added to the diet up to $30 \%$ (Arslan, 2013). One of the important characteristics of geese is their ability to consume green fodder and maintain their productivity on low protein diets. It also often enables the efficient use of new local

Page 2/21 
feed resources (Wang et al. 2017; Li et al. 2019; 2020). The seasonal habitat quality of the environment where the geese are raised also significantly affects their performance, reproduction and viability. By taking advantage of agricultural products in their wintering habitats, their food needs are met by the catabolism of the lipid reserves they accumulate and they contribute to an increase in survival rates (Wilson et al. 2016; Fowler et al. 2020). Stored endogenous nutrients are critical to the life cycle of arctic geese as they are used to supplement essential nutrients for long-distance migration, surviving harsh winters, and breeding (Massey et al. 2020).

On the other hand, economic feeding of geese is one of the main issues in goose production. Geese are usually bred for 13 weeks and are lubricated in oats for the last 3 weeks before slaughter. There is a possibility of breeding younger geese for slaughter covering 10-11 weeks without oat feeding (Buzala et al. 2014; Smulikowska and Rutkowski, 2019). Two methods are widely used in the feeding of geese for meat production in Turkey (Tilki et al. 2005; 2009; Saatçi et al. 2009), China (Liu et al. 2011) and Czech Republic (Uhlirova et al. 2018). One of which is the production of young geese whose slaughter age is 8-10 weeks, and the other one is slaughtered after 16 weeks of age (Tilki et al. 2005). These production patterns are the feeding practices of the producers, consumers and geese in those countries (Gumulka and Poltowicz, 2009). In line with the information given above, in our research, it is aimed to determine the most appropriate amount of silage for the successful management of the overwintering of geese in the winter months after 16 weeks old. Since there will be a decrease in the amount of concentrated feed consumed with silage application, it is expected that the production cost will decrease. In this study, the effects of corn silage substituted in different amounts instead of concentrated feed on the growth performance, carcass characteristics and yield, edible internal organ weights, digestive system length and weight, chemical composition and organoleptic characteristics of goose meat were investigated.

\section{Materials And Methods}

\section{Ethical Approval}

All experimental procedures were approved by Ondokuz Mayıs University Animal Experiments Local Ethics Committee with the decision dated 18.07.2019 and numbered 2019/32.

\section{Animal and housing}

A total of 35 male geese at 19 weeks of age used in the study were obtained from Yozgat Bozok University, Faculty of Agriculture. The research was carried out for 12 weeks in the windowed, naturally ventilated research cluster of Ondokuz Mayıs University Faculty of Agriculture during November-February 2020. The geese were raised individually in compartments with a floor area of $60 \times 190 \mathrm{~cm}^{2}$ ( 0.88 animals $\left./ \mathrm{m} 2\right)$. Wood shavings were laid in the compartments as a substrate. Each compartment was equipped with a drinker and a feeder. Feeders were hung at a height of $25 \mathrm{~cm}$ to minimize feed spillage.

\section{Experimental design and treatments}

The geese were fed under semi-intensive conditions until the 16th week and were acclimatized for three weeks before the trial. At 19 weeks of age, 35 geese of similar body weight (BW, $3646.40 \pm 174.73 \mathrm{~g}$ ) were selected and randomly allocated to 5 treatment groups and 7 replications. Feed was presented each animal at a calculated levels according to daily feed intake, and water was supplied as ad libitum. The treatments groups were: S00: Control group; S10: 10\% corn silage + 90\% concentrate feed; S20: $20 \%$ corn silage + $80 \%$ concentrate feed; S30: $30 \%$ corn silage $+70 \%$ concentrate feed; S40: $40 \%$ corn silage $+60 \%$ concentrate feed. The basal diet contained $2913 \mathrm{kcal} / \mathrm{kg}$ of metabolizable energy and $18 \%$ of crude protein (Table 1 ). 
For each goose in each group, $250 \mathrm{~g}$ of concentrate and silage feed per day and $1750 \mathrm{~g}$ per week were given with the same total weight. Geese were fed daily and excess feed in the animal's feeder weighed daily and also, feed consumption was determined. The animals were also not taken to pasture. It was determined that approximately $1 / 3$ of the silage given to the geese in the first week of the experiment, and they consumed the majority of the concentrate feed and silage given from the second week.

\section{Data collection}

Live weight gain, feed conversion and carcass characteristics were determined on a weekly basis. The feeders were removed from the chambers at 12 o'clock the night before the live weight weighing, and the animals were weighed at 8 am the next day. Concentrated feed + corn silage in pellet form was weighed daily. By weighing the remaining feed in the feeders at the same time the next day, it was ensured that there was no change in the dry matter of the corn silage. Live weight and feed were weighed on a scale with a precision of $1 \mathrm{~g}$. Considering the producer conditions in Turkey, all geese in the trial at 30 weeks of age were slaughtered manually to determine their growth performance and meat quality. After slaughter, the animals were kept in a hot water pool at $55^{\circ} \mathrm{C}$ for 2 minutes, then plucked using a plucking machine and the feet were cut from the Articulatio tarsi joint and separated from the thigh. The abdominal regions of the animals were opened along the midline and all internal organs in the abdominal and thoracic cavities were manually removed. For meat quality analysis, samples were collected from carcass, pectoral muscle (including pectoralis major and pectoralis minor), and thigh muscles. The carcass yield was determined by dividing the warm carcass weight ( without internal organs) by the pre-slaughter live weight. Digestive system weight, digestive system length, heart, liver, gizzard, abdominal fat weights and gizzard pH of slaughtered animals were taken. Abdominal fat levels were determined by weighing the fat around the abdomen, gizzard, heart, reproductive tracts and intestines. After the carcasses were kept at $+4{ }^{\circ} \mathrm{C}$ for 24 hours, they were weighed again and the cold carcass weight was determined. The sensory properties of goose meat were determined by taking $200 \mathrm{~g}$ breast meat in total from each treatment group and cooking it in water for 2 hours. Carcass, edible visceral and abdominal fat weights and digestive tract length were interpreted as \% of live weight and carcass by proportioning the slaughter body weight and carcass weight.

\section{Nutrient composition of meat}

Skinless breast and thigh meat of slaughtered geese were stored at $-18^{\circ} \mathrm{C}$. The chemical composition of meat (dry matter, crude protein, crude fat and ash) was determined according to the methods described by AOAC (1998).

\section{$L^{*}, a^{*}, b *$ and $\mathrm{pH}$ values of meat}

$L *, a *, b *$ values, color, brightness and $\mathrm{pH}$ value of meat play an important role in determining the quality of meat in consumers' taste (Ozturk et al. 2012; Dogan and Ozturk. 2019). Whole breast and thigh muscles (without separating parts) were used in the analysis after being stored 24 hours at $+4 \circ \mathrm{C}$. The color was measured on the surface of the muscles by three times. The color of thigh (biceps femoris) and breast (pectoralis major) muscles was analyzed with a colorimeter (Konica Minolta, model CR400, Tokyo, Japan). The color was graded according to the International Commission on Illumination' system for L* (lightness), a* (redness), and b* (yellowness) as previously described by Ozturk et al. (2012). Color was measured for each breast and thigh muscle from group once (seven measurements per group). Color ( $\mathrm{L} *$ : lightness, a: redness and b *: jaundice) with a colorimeter (Konica -Minolta CR 400, Sensing Inc., Japan) and pH with a pH meter (Model PC 510, Cyber scan, Singapore) carried out. All determinations were performed in triplicate.

\section{Sensory evaluation of meat}


Evaluation of the sensory properties of meat was carried out on the pectoral muscles of 5 geese from each group at a date after slaughter. For sensory analysis, samples were vacuum packed and stored at approximately $4^{\circ} \mathrm{C}$ for 5 days after dissection. After storage, the samples were boiled in water in closed containers for 150 minutes without salt or other seasonings (Dogan and Ozturk, 2019). Sensory characteristics were evaluated by 10 staff and graduate student panelists trained in methods according to ISO 8586-1 at Ondokuz Mayis University, Samsun, Turkey. Sensory characteristics were evaluated by 10 staff and graduate student panelists at Ondokuz Mayis University, Samsun, Turkey, who were trained with methods according to ISO 8586-1. The meats were presented to the panelists in a room under the light of fluorescent lamps at room temperature immediately after cooking. As the panelists moved from one meat to another, they were given water and fresh bread to counteract their sensory perceptions. Panelists rated appearance, hardness, flavor, tenderness, juiciness, chewiness, and overall acceptability using a 9-point hedonic scale (1; dislike extremely, 9; like extremely). The sensory analysis methodology with modifications for poultry meat was developed by Uhlirova et al. (2018)

\section{Instrumental analysis for meat quality}

\section{Mechanical properties}

Tissue profile analysis (TPA) was performed using a Texture Analyzer (TA-XT Plus, Stable Micro Systems, UK) with a $50 \mathrm{~mm}$ aluminum cylindrical probe (model P/50R) and a maximum $2 \mathrm{~kg}$ load cell (Öztürk and Turhan, 2020). The pretest speed was considered as $2 \mathrm{~mm} / \mathrm{s}$ with $5 \mathrm{~mm} / \mathrm{s}$ of test and post-test speed. An adapter with a 36 mm diameter cylinder was used. The goose meat was placed in a cylindrical bowl $15 \mathrm{~mm}$ in height and $30 \mathrm{~mm}$ in diameter. The adapter was $20 \mathrm{~mm}$ above the sample and then dropped at a rate of $30 \mathrm{~mm} / \mathrm{min}$. The adapter returned to its original position after entering a depth of $10 \mathrm{~mm}$. A 60\% compression rate was applied with double compression. The motion of the adapter was repeated once to complete the measurements. The parameters of TPA, namely hardness, adhesiveness, springiness, cohesion, chewing and resilience were determined using software provided by Stable Micro Systems Ltd (Anonymous, 2005).

\section{Statistical Analysis}

Arcsin transformation was applied to the percent values of the examined traits. Statistical analysis was evaluated with SPSS 21.0 (SPSS Inc., Chicago, IL, USA). Carcass characteristics and meat physical properties were analyzed by oneway analysis of variance. Sensory characteristics were analyzed with the Kruskal Wallis test. Statistical differences between the means in parametric methods were analyzed with Tukey test and in non-parametric methods with Dunn test $(\mathrm{P}<0.05)$.

\section{Results And Discussion}

\section{Live weight gain, feed consumption and feed conversion ratio}

The treatment groups consisting of different amounts of corn silage and concentrated feed had no significant effect on body weight gain, feed consumption and feed conversion rates of domestic geese $(P>005$, Table 2 and Table 3). During the trial period covering 19-30 weeks, the total feed consumption was 14925.1, 15736.8, 13940.9, 17006.4, $17304.2 \mathrm{~kg}$ in the trial groups, respectively. The treatments did not affect weight gain, feed consumption, and FCR because roughage and concentrate were not fed ad libitum to the geese. It has been determined that corn silage up to $40 \%$ can be used in goose compound feed without any negative effect on performance. The use of silage at this level will of course lead to a decrease in feed costs.

\section{Table 2}




\section{Table 3}

In previous study by Wang et al. (2017) reported that dried citrus pulp can be used at a level of $12 \%$ in geese without adverse effects on growth performance and carcass yield. Also, Chen et al. (2020) suggested that $75 \%$ of broken rice could be used to replace corn in goose (28 to 70 days) diets. In addition, a large number of researchers have investigated the effect of different feed ingredients on the performance of geese such as broken rice (Chen et al.2020), citrus pulp (Wang et al. 2017), rygrass-forage (Song et al. 2017; Guo et al. 2020), lupine (Kuzniacka et al. 2020), cassava foilage (Li et al. 2019; 2020), silage (Kokoszynski et al. 2014; Yin and Huang, 2016). Song et al. (2017) suggested that the BW of geese fed with grain fortified grass during the 70-day trial was $3647 \mathrm{~g}$, and an ideal fattening performance could be obtained due to the well-balanced diet of geese fed with a grass and grain supplement diet. In addition, higher feed consumption was found in the group that consumed more grass $(54.74 \mathrm{~kg})$ from pasture, confirming that geese were able to digest fiber in feed and ultimately had good growth performance (Song et al. 2017). However, the weight gains and final BWs of feed-only geese did not reach the market standard weight (3500 g) until day 70 due to the lack of crude protein and energy in the diet. Thus, it was emphasized that a grazing regime supported with grain is not only a method that can reach the standard weight of the market at 70 days of age, but also saves on grain feed. It was determined that $5 \%$ alfalfa substitution at the beginning and $10 \%$ during the growing period did not affect the live weight and feed consumption of the geese (Arslan, 2003).

Negative effects of low fiber diet (2.5\%) on growth performance, slaughter performance, serum biochemical parameters and food use $(6.1 \%$ and $4.3 \%$ according to fiber level) were found in geese up to 70 days (Li et al. 2017). This finding supports that geese, which are herbivorous poultry, need dietary fiber for normal performance. In contrast, Guo et al. (2020) attributed the gradual decrease in the BW of Yangzhou geese with increasing grass intake in the diet, which may be due to the low energy content of the grass, which decreased BW gain in proportion to the increased amount of grass in the diet. Li et al. (2019) 28-70. It has been reported that the addition of cassava foliage (5\%) to the goose diets improved carcass characteristics such as body weight gain, feed consumption, abdominal fat content and relative meat content. On the other hand, numerous studies on the use of roughage in Goose production have shown that moderate supplementation of roughage can improve growth performance, gastrointestinal tract development, nutrient digestibility, meat quality and microbial diversity (Wang et al. 2014; Jin et al. 2014; Liu and Zhou, 2013; He et al. 2015; Li et al. 2017; Li et al. 2020). It has been reported that fermented feeds have a significant effect on the caecal microflora composition of geese and can affect host growth, nutritional status and gut health (Yan et al. 2019). Similarly, Yin and Huang (2016) found that supplementing the basal goose diet with $8 \%$ fermented alfalfa grass had no significant adverse effects on growth performance, serum antioxidant enzyme activities and digestive parameters, and beneficial microbiota. It was determined that the use of cotton seed meal $(>6.73 \%)$ decreased the growth performance of the geese at an early age (28-42 days), and increased the growth performance of $6.73 \%$ to $26.91 \%$ CSM, 28 to 70 days of age (Yu et al. 2019). Liu et al. (2019), who investigated the feeding of wet feed, determined that wet feed had no effect on weight gain, but because it increased feed consumption and feed efficiency, dry feed was more suitable for 28-70-day-old geese. It was determined that the digestibility of DM, CP and NDF in the groups with high crude cellulose content was higher than the control group (Li et al. 2020). In contrast, Borin et al. (2006) reported lower apparent digestibility in chickens and ducks fed a diet supplemented with crude fiber. Geese have a more developed digestive system compared to chickens and ducks ( $\mathrm{Li}$ et al. 2020). Positive findings in nutrient digestibility reported with rice husk, whole corn, whole wheat, barley or oat supplementation (Vetési et al. 2000; Hetland et al. 2003; Amerah et al. 2009; Lu et al. 2011; Yang et al. 2016). Li et al. (2020) reported that the results obtained in their study can be explained by the fact that birds fed a high fiber diet probably have larger and more developed gizzard sizes. The larger gizzard may increase the grinding of feed, lead to greater exposure of nutrients to digestive juices and better food digestion (Wang et al. 2014; She et al. 2015). This shows that crude fiber may have beneficial effects on food digestibility in goose diets (Li et al. 2020). 


\section{Carcass characteristics}

There was no significant effect on slaughter weight and carcass yield, liver, gizzard and abdominal fat weights and ratios of the treatment groups (Table 4, P>0.05). The lack of effect of treatments on performance was due to the animals not being free fed. The fact that $\$ 20$ had a higher heart weight percentage than the others was thought to be due to trial measurement error. The fact that the maize silage substituted at the highest level (40\%) in the diet had similar carcass weight to the control group fed with fully concentrated feed confirms the hypothesis of this study.

\section{Table 4}

Kokoszyński et al. (2014) reported that dilution of the commercial diet alone with whole-crop maize silage for young fattening geese had a positive effect on production economy and carcass composition. In this study, 17-week-old geese carcasses contained more chest and thigh muscles and less skin and subcutaneous fat compared to the control group. Considering the decrease of nearly $50 \%$ in the consumption of commercial feed mixture in favor of cheaper corn silage, the fact that the production profitability of geese increased in this diet is parallel to our research. At 21.97 $\mathrm{kg}$ of silage consumption per goose (55\% of feed consumption), at the end of oat feeding (17 weeks), geese receiving silage had significantly longer bodies and drumsticks compared to fed geese (Kokoszyński et al. 2014). Geese fed diets containing $4.3 \%$ and $6.1 \%$ fiber had larger body sizes, heavier internal organs (heart, gizzard, proventricle, duodenum, jejunum, ileum, and cecum), compared to the $2.5 \%$ fiber group, with hot and cold carcass yield and breast yield was found to be greater (Li et al. 2017).

In contrast, Song et al. (2017) found that geese grazing reduces carcass yield, although the BW of geese with grainfortified grazing is similar to grain-only indoor geese. Similarly, carcass yield, breast yield and thigh yield of grass fed geese with supplemental grain were significantly higher than those of grass fed geese only. In contrast, Guo et al. (2020) when fed under intensive feeding conditions with ryegrass in a ratio of 1.5:1 or 2:1, will contribute to good growth performance and increase in meat essential amino acids, essential fatty acids, total amino acids, n-3 fatty acid, Zn, and SFA content, it has reported that it will provide high quality goose production. He et al. (2015) found that four different fiber sources (corn straw silage, steam-popped corn straw, wheat straw and rice straw) had no effect on CAA and carcass properties. These differences observed between studies may be related to the composition and consumption of different roughages.

Findings that roughage consumption increases the amount of abdominal fat and breast and thigh meat because it causes more energy intake (Liu and Zhou, 2013; Wang et al. 2014, Li et al. 2019) differed from our research. On the other hand, the finding of Arslan (2003) that the addition of alfalfa grass to the diet in the initial (5\%) and growing (10\%) periods leads to a better quality carcass by reducing the fat ratio of goose carcasses contradicts the results of these researchers. However, the above research findings that roughage consumption does not change slaughter weight and carcass yield are consistent with our research.

The effects of roughage on carcass characteristics and particularly relative meat production vary as they are influenced by bird species and digestive physiology. Normally, as the fiber content in the diet increases, these feeds with a lower digestible energy content but occupying more space in volume cause an increase in the volume of the digestive tract of the animal, thereby making the digestive tract volume and the weight of the digestive organs more compatible (Wang et al. 2014). ). Moreover, poultry fed a roughage diet have shorter intestinal components, a larger diameter, and higher intestinal surface area than those fed whole grain diets (Jin et al. 2014; Wang et al. 2014). In general, poultry with a higher relative weight or relatively longer length by different gastrointestinal tracts are considered more beneficial in terms of fiber source utilization. As a matter of fact, Li et al. (2019) stated that the roughage (Cassava foliage) diet increases the relative length and weight of the small intestine in geese, while more 
cellulose and less nutrient content in the same volume causes the digestive organs to grow and the frequency of contractions due to the physically enlarged gizzard wall. Jin et al. (2014), Wang et al. (2014), She et al. (2015) also reported that roughage supplementation had similar effects on geese. Song et al., (2017) claimed that geese would reach their full potential when allowed to consume grass from pasture fortified with grain, protein, collagen, $\mathrm{Mg}$ and $\mathrm{Cu}$ content, and that this feeding regimen is an ideal model for goose production.

\section{Nutrient content of meat}

Table 5 shows that there was no significant effect $(P>0.05)$ of treatments on crude protein, dry matter and ash values of goose breast meat. However, crude fat percentages were higher in S10, S20, S40 groups compared to S30 meats $(\mathrm{P}<0.05)$. This situation shows that since the geese were not fed in ad libitum diets, the physiological environment was not provided for excessive fattening of all groups.

\section{Table 5}

Goose is an important grass-fed poultry for meat. Thus, goose meat products are low-fat, low-cholesterol and highprotein (Fowler et al. 2018; Li et al. 2020). Tang et al. (2020) reported that the protein content of goose meat is $22.3 \%$, the fat content is $11 \%$, and more than $99 \%$ of the total fat consists of unsaturated fatty acids. The composition of the meat, especially the amount of fat, can vary according to the diet of geese (Boz et al. 2019). The nutritional composition of meat muscle (including protein, fat and collagen) is an important indicator of meat quality (Kuzniacka et al. 2020) and their amount constitutes nutritional value. As a matter of fact, consumers associate the smell, taste and flavor of a poultry product with its quality (Matyba et al. 2021; Karasu and Öztürk, 2018; Oğul and Öztürk, 2018; Doğan and Öztürk, 2019). Therefore, the nutrient content of meat is an important criterion in determining meat quality (Ozturk et al. 2010; 2014; Erener et al. 2011; Sarıca et al. 2014; Dogan and Ozturk, 2019). Marbling, known as intramuscular fat distribution, is considered as an element that improves meat quality, apart from other fats, as it positively affects the aroma and flavor of meat. Indeed, Lebret and Guillard (2005) and Arslan et al. (2003) reported that more protein and collagen and less fat accumulated in muscle in grazing geese, which may be due to the lower energy content of the feed. Kuzniacka et al. (2020) determined that protein and intramuscular fat content and water content in breast or thigh muscles were higher in the substituted lupine (30-35\%) groups than in the soybean meal group. Li et al. (2020), using cassava foliage (5\% and 10\%) as roughage, reported that there was no difference between the treatments in terms of dry matter, crude protein and crude oil ratios. On the other hand, Arslan (2013) showed that the growth rate in pasture-based feeding was slower than in intensive and semi-intensive feeding, but low-fat carcass was obtained. The protein content and muscle collagen in breast and thigh meats were higher and the fat content was lower in the grazing treatment compared to the control (Song et al. 2017).

Physiological studies on how nutrient content changes in goose meat tissue are limited. One of the rare studies on this subject showed that differentially expressed genes related to the insulin signaling pathway can increase protein synthesis and fat production, and that the interaction network of these genes is mainly related to the endocrine system. The differentially expressed genes related to the growth and function of the pituitary organs can regulate the growth and development of the body by affecting the synthesis and secretion of pituitary hormones, which will help to understand the regulatory mechanism of goose growth and development (Tang et al. 2020). Due to the complexity of the processes involved in the synthesis and catabolization of proteins, waterfowl typically use their protein stores as an energy source in extreme situations where lipid stores are depleted (Blem, 1990). It has been observed that the nutrients in goose meat can also change seasonally, protein stores are more stable than lipids and slightly increase as winter progresses, lipid stores are highest in November and lowest in February. It has been determined that there is an increase in endogenous lipid stores of geese at the beginning of winter, when high-energy food sources are most abundant, and a decrease as winter progresses (Massey et al. 2020). Fat ratio in meat may vary depending on the 
animal's breed, age, energy/protein ratio in feed, balance of nutrients in the diet and production system (Ozturk et al. 2012; Hughes et al. 2014; Boz et al. 2017; Uhlirova et al. 2018; Haraf et al. 2021).

\section{Physicochemical Traits}

Feeding domestic geese with different amounts of corn silage and concentrate had no effect on $a^{\star}, b^{\star}$ and $p H$ values of breast and thigh meats $(P>0.05)$. On the other hand, while S00 and S10 had the highest value in breast meat $L^{*}$ value, S20 and S30 groups followed these groups, while S40 was at the lowest level (Table 6). The $L^{*}$ value of thigh meat was lower in the $\mathrm{S} 40$ group than all other groups $(\mathrm{P}<0.05)$, and there was no difference among the other groups.

\section{Table 6}

Kuzniacka et al., (2020) determined that the addition of lupine instead of soybean meal to the diet did not have a negative effect on goose meat color and water holding capacity and meat characteristics, but negatively affected growth performance. On the other hand, Song et al. (2017), Wang et al. (2009) and Liu et al. (2011)'s findings on different feeding regimes did not change the $\mathrm{pH}$ values of goose meat are similar to our study. Also, the findings of Kuzniacka et al. (2020), who reported that the $\mathrm{pH}$ value of the meat was higher (7.9-8.2) in the soybean meal group, differs from our study. While consumers primarily consider issues such as the price, appearance and color of meat when purchasing meat, the most determining factor as a quality criterion is actually color (Sarıca and Yamak, 2010; Karasu and Öztürk, 2018; Ogul and Ozturk, 2018; Dogan and Ozturk, 2019; Li et al., 2020). The surface colors of meat are largely controlled by pigments composed of myoglobin, hemoglobin and cytochrome $\mathrm{C}$. There is a positive correlation between total pigment concentration and Fe and $a^{*}$ value, and a negative correlation with $L^{*}$ value. In particular, meat with a high a* value has a darker color (Boulianne and King, 1998). It has been shown that roughage or high level fiber content increases the $L^{*}$ value in geese (Castellini et al., 2002) and broilers (Liu et al., 2013) and lowers the final $\mathrm{pH}$ of the goose or broiler. Using cassava foliage (5\% and 10\%) as roughage, Li et al. (2020) reported that there was no difference between the treatments in $a^{*}$ and $b^{*}$ values. They found an increase the $\mathrm{pH}$ and shear force of the breast muscle and a decrease in $L^{*}$ values in the control group. Shrinkage caused by low $\mathrm{pH}$; It can be explained by the shrinkage of the fibers, decreasing the water binding ability and increasing the light scattering (Warriss, 2000). pH value, which is an important index of meat quality, is one of the factors affecting shelf life. The pH determined in our study was similar to the $\mathrm{pH}$ level found in thigh or breast meat of Yakan et al. (2012) and Sarıca et al. (2014) who experimented under extensive conditions in Turkish geese (32-36 weeks old), Boz et al. (2019) was found to be higher the $\mathrm{pH}$ values (5.74 to 7.02) reported in other studies with local Turkish geese (Kirmizibayrak et al. 2011; Boz et al. 2017) were similar to or lower than those in this study. PH values may vary depending on age, production system and nutrition (Hughes et al.2014; Boz et al. 2019).

Breast meat consists of white, thigh meat consists of red fibers. Red fibrils contain more myoglobin, less glycogen and glycolytic enzymes than white fibrils (Aberle et al. 2001). Therefore, although it has been reported that the $\mathrm{pH}$ in thigh meat is higher than breast meat (Oz and Çelik, 2015; Boz et al. 2019), in our study, a relatively higher pH was found in breast meat, which is close to each other. Properties such as $\mathrm{pH}$ value, water holding capacity, cooking loss, hardness, springiness, stickiness, cohesion, chewiness, color and shelf life are effective features in determining meat quality (Ozturk et al. 2012; Dogan and Ozturk, 2019; Kuzniacka et al. 2020). While the decrease in the pH of the meat decreases the bacterial load, the increase in the $\mathrm{pH}$ shortens the shelf life of the meat as it increases the pathogenic microbial load (Şekeroğlu and Diktaş, 2012; Ozturk et al. 2012; Dogan and Ozturk, 2019). In addition, high pH causes an undesirable appearance (dry, firm and darker color) in meat and a firmer appearance by preventing intramuscular protein degradation (Sarica et al. 2014). A pH below 5.7 in meat is considered an indicator of low meat quality (Alvarado et al. 2007). Boz et al. (2019) reported that the differences between meat color of geese and commercial lines may be related to late slaughter age (28 weeks) and pasture feeding. Boz et al. (2019) attributed the color and pH 
differences to the body weight difference in domestic goose varieties, while Liu et al. 2011; Yalçın et al. 2014 ; Boz et al. (2017) attributed meat quality characteristics such as $\mathrm{pH}$, color and dry matter to growth characteristics, growth rate and body weight. Hughes et al. (2014) reported that the color and $\mathrm{pH}$ of meat may change depending on age, production system and feeding. Li et al. (2020) found that the $\mathrm{pH}$ of breast meat was higher in the control group than in the groups with high crude cellulose content. Similar results were obtained by Liu et al. (2013) in geese and by Castellini et al. (2002) in broilers by Mourăo et al. (2008). This finding could possibly be attributed to the fact that feed intake improves the carbohydrate level and thus decreases glycogen metabolism, which can maintain the acid-base balance in the animal (Castellini et al. 2002; Foulkes and Cohen, 2010; Li et al.2020).

\section{Texture profile analysis and organoleptic quality characteristics of meat}

Since the determination of meat quality made by organoleptic methods is subjective, the quality characteristics of goose meat were also determined objectively by analyzing the texture profile (Öztürk and Turhan, 2020) (Figure 1). There was no difference between the treatment groups in terms of springiness, cohesiveness, chewiness and resilience characteristics ( $P>0.05$, Figure 1). Hardness $(N)$ values decreased with the addition of silage $(P<0.05)$, except for the S20 group. This observed trend can be interpreted as a general decrease in the firmness of goose meat with the addition of silage to the diet. On the other hand, in terms of adhesiveness, which is an indicator of unhealthy meat, S00 was found to be higher than the other groups $(P<0.05)$. The decrease in adhesiveness and hardness in meat as the silage substitution in diet increases is a very good development in terms of increasing consumer appreciation for meat.

\section{Figure 1}

It is desirable that fresh meat be firm, brightly colored, with no broth separated and with little binding texture. In contrast, hardness may result from increased connective tissue in the meat or from rigor motility after slaughter. On the other hand, the fact that the meat is softer indicates that the intramuscular fat tissue increases, in other words, the amount of marbling increases. On the other hand, the concentration of fat in other parts of the body, such as shell fat, rather than in the form of marbling, causes a decrease in fat between the muscles and further hardening of the meat (Öztürk and Turhan, 2020). Although no results were obtained in our study to support this finding in meat fat analysis, the decrease in hardness in texture profile analysis can be interpreted as an increase in meat marbling. This shows that the addition of corn silage instead of concentrated feed to the diet of domestic geese reduces the hardness of the meat and provides soft meat that is more suitable for consumers. According to the organoleptic meat quality test, there was no difference between the treatment groups in terms of sensory quality characteristics (appearance, flavour, hardness, tenderness, juiciness, chewiness and overall acceptability) of goose meat (Table 7, P>0.05).

\section{Table 7}

Physical properties such as meat color and water holding capacity play an important role in the quality assessment of meat and meat products (Barbera et al. 2019; Oğul and Öztürk, 2018; Doğan and Ozturk, 2019). These properties also affect the suitability of raw meat for further processing and the economy of meat production. The quality of meat obtained from broiler geese depends on genotype, age and management system, especially diet (Uhlirova et al., 2018). The quality and quantity of muscle tissue in the carcass depends on the composition of the feed used in their diet (Ozturk et al. 2010; 2012; 2014; Kuzniacka et al. 2020).

Numerous studies on the use of roughage in goose production have shown that moderate supplementation of roughage can improve growth performance, gastrointestinal tract (GIT) development, nutrient digestibility, meat quality and microbial diversity (Liu and Zhou, 2013; Wang et al. 2014; Jin et al. 2014; He et al. 2015; Li et al. 2017). Supporting 
the findings of these researchers, Kuzniacka et al. (2020) reported that the inclusion of broad beans in the goose diet had a positive effect on meat quality. Geese can reach their full potential when allowed to consume grass from pasture fortified with grain, protein, collagen. Indeed, Song et al. (2017) found that leg yields were lower in the grain fed regimen compared to the grazing groups. This result shows that geese can produce a higher thigh yield with the grazing model (Castellini et al. 2002), indicating that this roughage replacement feeding regimen is an ideal model for goose production. Shearing force is an index to evaluate the tenderness of meat, and meat with lower cutting force is softer. Li et al. (2020) stated that the shear force in control geese was higher than in those fed diets with higher crude fiber diets. On the other hand, Liu and Zhou (2013) found that the consumption of meadow grass had no effect on shear force in goose meat. This inconsistency in results may be related to forage composition and consumption.

\section{Conclusion And Recommendations}

It was determined that up to $40 \%$ of corn silage mixed feed could be used especially in winter feeding where roughage could not be supplied sufficiently. Thus, it was concluded that the cost of local breed goose diets will be reduced and a contribution to sustainable goose production will be provided. On the other hand, it was determined that the stickiness and hardness values of goose meat improved with the addition of roughage. These findings, which contribute positively to the taste of meat, will contribute positively to the increase in the taste of meat in consumers and the evaluation of goose meat in the food industry.

\section{Declarations}

\section{Acknowledgements}

Research was supported by Technical Research Council of Turkey (TUBITAK) 2209A / International Research Projects Support Program (Application Number: 1919B011900752). We thank to TÜBiTAK for providing financial support to our project. We are grateful to the Geese Institute of Bozok University and Ondokuz Mayis University for offering the experimental place and animals. We also thank Arif Darmawan from IPB University for checking English grammar of the article.

This study was carried out in accordance with the Animal Rights and Experiment Ethical principles with the decision of Ondokuz Mayıs University Animal Experiments Local Ethics Committee, dated 18.07.2019 and numbered 2019/32.

Conflicts of Interest: The authors declare no conflict of interest. The funders had no role in the design of the study; in the collection, analyses or interpretation of data; in the writing of the manuscript, or in the decision to publish the results.

\section{References}

1. Aberle, E. D., Forrest, J., Gerrard, C.D.E., Mılls, E.W., Hedrıck, H.B., Judge, M.D. and Merkel, R.A., 2001. Structure and composition of animal tissues. Princ. Meat Sci. 4. edition. (Kendall Hunt Pub Co, UK)

2. Abou-Kassem, D.E., Ashour, E.A., Alagawany, M., Mahrose, K.M., Rehman, Z.U. andDing, C., 2019. Effect of feed form and dietary protein level on growth performance and carcass characteristics of growing geese, Poultry Science. 98 (2) 19, 761-770

3. Alvarado, C. Z., Richards, M.L., Keefe, S.F.O. and Wang, H.,. 2007. The effect of blood removal on oxidation and shelf life of broiler breast meat, Poultry Science, 86 (1), 156-161 
4. Amerah, A. M., Ravindran, V. and Lentle, R. G., 2009. Influence of insoluble fibre and whole wheat inclusion on the performance, digestive tract development and ileal microbiota profile of broiler chickens, British Poultry Science, 50(3), 366 375, https://doi:10.1080/00071660902865901

5. Ankom, 2003. Method for determining neutral detergent fiber, acid detergent fiber, crude fiber. Ankom Technology, Macedon, NY.

6. Anonymous, 2005. Stable Micro Systems Ltd., 6.0.5.0 TEE32 MFC Application: Surrey, England.

7. AOAC, 1998. Officinal Methods of Analysis of AOAC International. 16th Edition, Association of Official Analytical Chemists, Washington, DC

8. Arslan, C.,2013. Goose Nutrition and Breeding, (Kars, Medipres)

9. Arslan, C. and Saatci, M., 2003. Bulky feeds in the intensive fattening of goslings. I. Effects of grass, alfalfa and sugar beet pulp on growth, slaughter performance and some blood parameters in geese. Revue de Medecine Veterinaire, 154 (10), 633-638

10. Barbera, S., 2019. WHC trend, an up-to-date method to measure water holding capacity in meat, Meat Science, 152 , 134-140, doi: 10.1016/j.meatsci.2019.02.022

11. Blem, C.R., 1990. Avian energy storage. Current Ornithology, 7,59-113

12. Borin, K., Lindberg, J.E. and Ogle, R.B., 2006. Digestibility and digestive organ development in indigenous and improved chickens and ducks fed diets with increasing inclusion levels of cassava leaf meal. Journal of Animal Physiology and Animal Nutrition, 90(5-6), 230-237, https://doi:10.1111/j.1439-0396.2005.00586.x

13. Boz, M.A.,Sarica, M and Yamak, U.S., 2017. Production traits of artificially and naturally hatched geese in intensive and freerange systems - II: slaughter, carcass and meat quality traits. British Poultry Science, 58 (2), 166-176, https://doi.org/10.1080/00071668.2016.1261998

14. Boz, M.A., Oz, F., Yamak, U.S., Sarica, M. and Cilavdaroglu. E., 2019. The carcass traits, carcass nutrient composition, amino acid, fatty acid, and cholesterol contents of local Turkish goose varieties reared in an extensive production system. Poultry Science, 98 (7) 3067-3080, doi: 10.3382/ps/pez125

15. Buzała, M., Adamski, M. and Janicki, B., 2014. Characteristics of performance traits and the quality of meat and fat in Polish oat geese. World PoultryScience Journal, 70 (03), 531-542, https://doi:10.1017/s0043933914000580

16. Castellini, C., Mugnai, C. And Bosco, A.D., 2002. Effect of organic production system on broiler carcass and meat quality. Meat Science, 60 (3), 219-225,https://doi:10.1016/S0309-1740(01)00124-3.

17. Chen, X., Yang, H., Xu, L., Wan, X. and Wang, Z., 2020. Effect of Replacing Dietary Corn with Broken Rice on Goose Growth Performance, Body Size and Bare Skin Color. Animals, 10 (8): 1330, doi: 10.3390/ani10081330

18. Clausen, K.K., Madsen, J., Cottaar, F., Kuijken, E. and Verscheure, C., 2018. Highly dynamic wintering strategies in migratory geese: coping with environmental change. Global Change Biology, 24 (07), 3214-3225, https://doi:10.1111/gcb.14061

19. Cui, L.L., Wang, J.F., Xie, K.Z., Li, A.H., Geng, T.Y., Sun, L. R., Liu. J.Y., Zhao, M., Zhang, G.X. and Wang, J.Y., 2015. Analysis of meat flavor compounds in pedigree and two-strain Yangzhou geese. Poultry Science, 94 (9), $2266-$ 2271. doi:10.3382/ps/pev179

20. Dogan, E. and Ozturk, E., 2019. The effect of fresh and aged garlic extract-enriched diets on the growth performance of broilers and the oxidative rancidity and customer acceptance of chicken meat. Turkish Journal of Agriculture-Food Science and Technology, 7(12), 2267-2274

21. Erener, G., Ocak, N., Altop, A., Cankaya, S., Aksoy, H. andOzturk, E., 2011. Growth performance, meat quality and caecal coliform bacteria count of broiler chicks fed diet with green tea extract. Asian-Australasian Journal of

Page $12 / 21$ 
Animal Sciences. $24(8), 1128-1135$

22. FAO. 2016. Food and agriculture organization of the united nations statistics division database. http://faostat3.fao.org, accsessed on 21 April, 2017.

23. Foulkes, J. G., and P. Cohen. 2010. The regulation of glycogen metabolism. Purification and properties of protein phosphatase inhibitor-2 from rabbit skeletal muscle. European Journal of Biochemistry, 105,195-203

24. Fowler, D. N., Kuechle, K. J., Woodall, B. A., Vrtiska, M. P. and Webb, E. B.. 2018. Evaluating indices of lipid and protein content in lesser snow and Ross's geese during spring migration. Wildlife Society Bulletin, 42 (2):295303. https://doi.org/10.1002/wsb.867

25. Fowler, D., Webb, E., Vrtiska, M. and Hobson, K. 2020. Winter carry-over effects on spring body condition driven by agricultural subsidies to Lesser Snow Geese (Anser caerulescens caerulescens). Avian Conservation and Ecology, 15(2), 21. https://doi.org/10.5751/ACE-01743-150221

26. Gumulka, M., Wojtysiak, D., Kapkowska, E.,Poltowicz, K. and Rabsztyn, A., 2009. Microstructure and technological meat quality of geese from conservation flock and commercial hybrids. Annals of Animal Science, 9 (5)205-213

27. Gumulka, M. And Poltowicz, K., 2020. Comparison of carcass traits and meat quality of intensively reared geese from a Polish genetic resource flock to those of commercial hybrids, Poultry Science, 99 (2),839-847, https://doi.org/10.1016/j.psj.2019.10.042

28. Guo, B., Li, D., Zhou, B., Jiang, Y., Bai, H., Zhang, Y., Xu, Q., Yongzhang. and Chen, G. (2020). Research Note: Effect of diet with different proportions of ryegrass on breast meat quality of broiler geese. Poultry Science, 99 (5), 2500-2507, doi:10.1016/j.psj.2019.10.039

29. Haraf, G., Wołoszyn, J., Okruszek A., Goluch, Z., Wereńska, M. and Teleszko, M., 2021. Section: Processing and Products The protein and fat quality of thigh muscles from Polish goosevarieties, Poultry Science, 100(4), 100992, https://doi.org/10.1016/j.psj.2021.01.015

30. He, L.W., Meng, Q.X., Li, D.Y., Zhang, Y.W. and Ren, L.P. 2015. Effect of different fibre sources on performance, carcass characteristics and gastrointestinal tract development of growing Greylag geese, British Poultry Science, 56(1), 88-93. https://doi:10.1080/00071668.2014.981503

31. Hetland, H., Svihus, B. and Krogdahl, A., 2003. Effects of oat hulls and wood shavings on digestion in broilers and layers fed diets based on whole or ground wheat. BritishPoultry Science, 44,275-282

32. Hughes, J.M.,Kearney, G. and Warner, R.D., 2014. Improving beef meat colour scores at carcass grading. Animal Production Science, 54:422-429, http://dx.doi.org/10.1071/AN13454

33. Jin, L., Gao, Y., Ye, H., Wang, W., Lin, Z., Yang, H., Huang, S. and Yang, L.,2014. Effects of dietary fiber and grit on performance, gastrointestinal tract development, lipometabolism, and grit retention of goslings. Journal of Integrative Agriculture, 13(12), 2731-2740. http://doi:10.1016/s2095-3119(13)60729-7

34. Karasu, K. and Öztürk, E., 2018. Perception of Product Quality, Attitudes and behaviors of consumers in Istanbul province through feeding broiler chickens,(unpublised MSc thesis, Ondokuz Mayis University)

35. Karasu, K. and Öztürk, E., 2020. The Effects of Genetically Modified Feeds on Consumers' Preferences in Buying Broiler Meat. Austin Journal of Nutrition \& Metabolism, 7(4), id1087

36. Kirmizibayrak, T., Onk, K., Ekiz, B.,Yalçintan, H.,Alçintan, H.,Yilmaz, A., Yazici, K. and Altinel, A., 2011. Effects of age and sex on meat quality of Turkish native geese raised under a free-range system. Kafkas Universitesi Veteriner Fakultesi Dergisi, 17(5), 817-823

37. Kokoszyński, D., Bernacki, Z., Grabowicz, M. and Stańczak, K.,2014. Effect of corn silage and quantitative feed restriction on growth performance, body measurements, and carcass tissue composition in White Kołuda W31 geese.Poultry Science, 93(8), 1993-1999

Page 13/21 
38. Kutlu, H.R., 2008. Feed Evaluation and Analysis Methods. Çukurova University, Faculty of Agriculture Lecture Notes. Adana

39. Kuźniacka, J., Hejdysz, M., Banaszak, M., Biesek, J., Kaczmarek, S., Grabowicz, M., Rutkowski, A. and Adamski, M., 2020. Quality and physicochemical traits of carcasses and meat from geese fed with lupin-rich feed. Animals, 10(3), 519, http://doi:10.3390/ani10030519

40. Lebret, B. and Guillard, A.S., 2005. Outdoor rearing of cull sows: effects on carcass, tissue composition and meat quality. Meat Science, 70: 247-257http://doi:10.1016/j.meatsci.2005.01.007

41. Li, M., Zhou, H., Pan, X., Xu, T., Zhang, Z., Zi, X. and Jiang, Y., 2017. Cassava foliage affects the microbial diversity of Chinese indigenous geese caecum using 16S rRNA sequencing. Scientific Reports, 7:45697, https://doi:10.1038/srep45697

42. Li, M., Zhou, H., Xu, T. and Zi, X., 2019. Effect of cassava foliage on the performance, carcass characteristics and gastrointestinal tract development of geese. Poultry Science, 98(5), 2133-2138, https://doi:10.3382/ps/pey567

43. Li, M., Zi, X., Tang, J., Xu, T., Gu, L. and Zhou, H., 2020. Effects of cassava foliage on feed digestion, meat quality, and antioxidative status of geese. Poultry Science, 99(1), 423-429, https://doi:10.3382/ps/pez522

44. Liu, B., Wang, Z., Yang, H., Wang, J., Xu, D., Zhang, R. and Wang, Q., 2011. Influence of rearing system on growth performance, carcass traits and meat quality of Yangzhou geese. Poultry Science, 90: 653-659, https://doi:10.3382/ps.2009-00591

45. Liu, H.W. and Zhou, D.W., 2013. Influence of pasture intake on meat quality, lipid xidation, and fatty acid composition of geese.Journal of Animal Science. 91,764-771, https://doi.org/10.2527/jas.2012-5854

46. Lu, J., Kong, X.L., Wang, Z.Y., Yang, H.M., Zhang, K.N. and Zou, J.M., 2011. Influence of whole corn feeding on the performance, digestive tract development, and nutrient retention of geese. Poultry Science, 90,587-594, https://doi:10.3382/ps.2010-01054

47. Massey, E.R., Carlson,L.G. and Osborne, D.C., 2020. Temporal trends in body condition of arctic geese wintering in the Mississippi Alluvial Valley. Journal of Fish and Wildlife Management 11(1),11-21, e1944-687X, https://doi.org/10.3996/062018-JFWM-047

48. Matyba, P., Florowski, T., Dasiewicz, K., Ferenc, K., Olszewski, J., Trela, M., Galemba, G., Słowinski, M., Sady, M.,Domanska, D., Gajewski, Z. and Zabielski, R., 2021. Performance and meat quality of intrauterine growth restricted pigs. Animals, 11, 254. https://doi.org/10.3390/ani11020254

49. Oğul, M. and Ozturk, E., 2018. The attitudes, behavior and perceptions of the people living in Samsun about organic animal production,, (unpublised MSc thesis, Ondokuz Mayis University) Oz, F. and Celik, T., 2015. Proximate composition, color and nutritional profile of raw and cooked goose meat with different methods,Journal of Food Processing and Preservation, 39(6), 2442-2454, https://doi:10.1111/jfpp.12494

50. Ozturk, E., Coskun, I., Dervisoglu, M., Turhan, S., Ocak N. and Erener G., 2014. Performance, meat quality, meat mineral contents and caecal microbial population responses to humic substances administered in drinking water in broilers. British Poultry Science, 55 (5): 668-674, http://dx.doi.org/10.1080/00071668.2014.960807

51. Ozturk, E., Ocak, N., Coskun, I., Turhan, S. and Erener, G., 2010.Effects of humic substances supplementation provided through drinking water on performance, carcass traits and meat quality of broilers. Journal of Animal Physiology and Animal Nutrition,94(1), 78-85 https://doi.org/10.1111/j.1439-0396.2008.00886.x

52. Ozturk, E., Ocak, N.,Turan, A., Erener, G., Altop, A. and Cankaya, S., 2012. Performance, carcass, gastrointestinal tract, meat quality traits and selected blood parameters of broilers fed diets supplemented with humic substances, Journal of the Science of Food and Agriculture, 92(1), 59-65, https://doi.org/10.1002/jsfa.4541. 
53. Öztürk, T. and Turhan, S., 2020. Physicochemical properties of pumpkin (Cucurbita pepo L.) seed kernel flour and its utilization in beef meatballs as a fat replacer and functional ingredient, Journal of Food Processing and Preservation, 44 (9), e14695, https://doi:10.1111/jfpp.14695

54. Sarica, M. and Yamak, U.S., 2010. Developing slow growing meat chickens and their properties. Anadolu Journal of Agriculture Science 25, 61-67

55. Sarica, M., Boz, M.A. and Yamak, U.S., 2014. Meat quality traits and some blood parameters of white and multicolor geese reared in backyard in Yozgat, Anadolu Journal of Agriculture Science, 29,147-153

56. Sekeroglu, A. and Diktas, M., 2012. Effect of free fange production system on slower-growing broiler carcass characteristics and meat quality. Kafkas Universitesi Veteriner Fakultesi Dergisi, 18,1007-1013.

57. Smulikowska, S. and Rutkowski, A., 2019. Nutritional Recommendations and Nutritional Value of Poultry Feeds. Cooperative Work. In Fifth Edition-Changed and Supplemented; Institute of Physiology and Animal Nutrition: Jabłonna, Poland.

58. Song, Y., Li, Y., Zheng, S., Dai, W., Shen, X., Zhang, Y., Xu, Q. andChen, G.,2017. Effects of forage feeding versus grain feeding on the growth performance and meat quality of Yangzhou geese. British Poultry Science, 58(4),397401, https://doi:10.1080/00071668.2017.1307942

59. Tang, J., Shen, X., Ouyang, H., Luo, W., Huang, Y., Tian, Y. and Zhang, X., 2020. Transcriptome analysis of pituitary gland revealed candidate genes and gene networks regulating the growth and development in goose. Animal Biotechnology, 1-11. doi: 10.1080/10495398.2020.1801457

60. Tilki, M., Saatci, M., Kirmizibayrak, T. andAksoy. A., 2005. Effect of age on growth and carcass composition of Native Turkish Geese. European Poultry Science, 69,77-83

61. Uher-Koch, B.D., Buchheit, R.M., Eldermire, C.R., Wilson, H.M.and Schmutz, J.A., 2021. Shifts in the wintering distribution and abundance of emperor geese in Alaska. Global Ecology and Conservation, 25, e01397, https://doi.org/10.1016/j.gecco.2020.e01397

62. Uhlirova, L., Tumova, E.,Chodova, D.,Vlckova, J.,Ketta, M.,Volek, Z. andSkrivanova V., 2018. The effect of age, genotype and sex on carcass traits, meat quality and sensory attributes of geese. Asian-Australasian Journal of Animal Science, 31,421-428

63. Van Soest, P.V., Robertson, J.B. andLewis, B.A.,1991. Methods for dietary fiber, neutral detergent fiber, and nonstarch polysaccharides in relation to animal nutrition. Journal of Dairy Science, 74(10), 3583-3597.

64. Yalcin, S., Guler, H.C.,Yasa, I.,Gamze, T.T. and Sezen, O., 2014. Effect of breeder age and slaughter weight on meat quality traits of broiler breast and leg meats. European Poultry Science, 78. https://doi:10.1399/eps.2014.45

65. Vetési, M., Orosz, S. and Mézes. M,. 2000. Influence of feeding diets with barley or oat to growing geese on performance, digestibility of nutrients and concentration of VLDL, triglyceride and cholesterol in blood plasma. European Poultry Science,. 64,219-223

66. Wang, C., Gao, G.L., Huang, J. X., Zhang, K.S., Zhong, H., Wang, H.W., Su, J., Xie, M. and Wang, Q.G., 2017. Nutritive value of dry citrus pulp and its effect on performance in geese from 35 to 70 days of age, The Journal of Applied Poultry Science, 26,253-259, https://doi:10.3382/japr/pfw069

67. Wang, K., Shı, S., Dou, T. and Sun, H., 2009. Effect of a free-range raising system on growth performance, carcass yield and meat quality of slow-growing chicken. Poultry Science, 88, 2219-2223, https://doi:10.3382/ps.200800423

68. Wang, Z.Y., Yang, H.M., Lu, J., Li, W.Z.and Zou,J.M.,2014. Influence of whole hulled rice and rice husk feeding on the performance, carcass yield and digestive tract development of geese, Animal Feed Science and Technology, 194, 99-105, https://doi:10.1016/j.anifeedsci.2014.04009

Page $15 / 21$ 
69. Warriss, P.D. 2000. Meat science: an introductory text. International Journal of Food Science and Technology, 36(4), 449-449, https://doi:10.1046/j.1365-2621.2001.0437a.x

70. Mourao, J.L., Pinheiro, V.M., Prates, J.A.M., Bessa, R. J.B., Ferreira, L.M. A., Fontes, C.M.G.A. and Ponte, P.I.P.,2008. effect of dietary dehydrated pasture and citrus pulp on the performance and meat quality of broiler chickens. Poultry Science, 87(4), 733-743. https://doi:10.3382/ps.2007-00411

71. Wilson, S.,Alisauskas, R.T. and Kellett, D.K.,2016. Factors influencing emigration of Ross's and snow geese from an Arctic breeding area. Journal of Wildlife Management, 80,117-126, https://doi.org/10.1002/jwmg.960

72. Yakan, A.,Elmali, D.A.,Elmali, E.,Sahin, T., Motor, S. and Can, Y., 2012. Carcass and meat quality characteristics of white and multicolor geese under local breeder conditions. Kafkas Universitesi Veteriner Fakultesi Dergisi,18, 663670

73. Yan, J., Zhou, B., Xi, Y., Huan, H., Li, M., Yu, J., Zhu, H., Dai, Z., Ying, S., Zhou, W. and Shi, Z.,2019. Fermented feed regulates growth performance and the cecal microbiota community in geese. Poultry Science, 98(10), 4673-4684, https://doi.org/10.3382/ps/pez169

74. Yang, J., Zhai, S., Wang, Y., Wang, S., Yang, Z., Yang, L. and Wang, W., 2016. Effects of graded fiber level and caecectomy on metabolizable energy value and amino acid digestibility in geese. Journal of Integrative Agriculture, 15(3), 629-635, https://doi:10.1016/s2095-3119(15)61071-1

75. Yin, H.C. and Huang, J.,2016. Effects of soybean meal replacement with fermented alfalfa meal on the growth performance, serum antioxidant functions, digestive enzyme activities, and cecal microflora of geese, Journal of Integrative Agriculture, 15(9), 2077-2086

76. Yu, J., Wang, Z.Y., Yang, H.M., Xu, L. and Wan, X.L.,2019. Effects of cottonseed meal on growth performance, small intestinal morphology, digestive enzyme activities, and serum biochemical parameters of geese. Poultry Science, 98(5):2066-2071, https://doi:10.3382/ps/pey553

77. Zhang, S. J., Zhu, C.H., Guo, J., Tang, Q.P., Li, H.F. and Zou, J. M., 2013. Metabolizable energy and fiber digestibility of uncommon feedstuffs for geese. Poultry Science, 92(7), 1812-1817, https://doi:10.3382/ps.2012-02515

\section{Tables}

Table 1 Nutrient composition of basal diet and corn silage used in the experiment 
Diet $\quad$ Corn silage ${ }^{4}$

(in DM)

\begin{tabular}{lll}
\hline Chemical Analysis & & \\
\hline Protein, \% & 18.00 & 8.8 \\
\hline Fat, \% & 4.65 & 3.2 \\
\hline Fiber, \% & 4.58 & 23.4 \\
\hline Ash, \% & 5.19 & 4.3 \\
\hline Calculated Values & & \\
\hline Metabolizable Energy, kcal/kg & 2913 & $2563^{3}$ \\
\hline Lisine, \% & 0.93 & $2.2^{2}$ \\
\hline Methionine, \% & 0.43 & $1.1^{2}$ \\
\hline Methionine+Cystine, \% & 0.79 & $2.2^{2}$ \\
\hline Threonine, \% & 0.75 & $2.7^{2}$ \\
\hline Tryptophan, \% & 0.21 & $1.5^{2}$ \\
\hline Calcium, \% & 0.93 & $3.4^{2}$ \\
\hline Total phosphorus, \% & 0.65 & $2.1^{2}$ \\
\hline Available phosphorus, \% & 0.43 & \\
\hline Sodium, \% & 0.18 & $0.1^{2}$ \\
\hline
\end{tabular}

${ }^{1}$ Vitamins and minerals contained in each kg diet; $12000 \mathrm{IU}$ of Vitamin A; $2400 \mathrm{IU}$ of vitamin D3; $40 \mathrm{mg}$ of vitamin E; 4 $\mathrm{mg}$ of vitamin $\mathrm{K} 3 ; 3 \mathrm{mg}$ of vitamin B1; $6 \mathrm{mg}$ of vitamin B2; $25 \mathrm{mg}$ of niacin; $10 \mathrm{mg}$ of calcium-D-pantothenate; $5 \mathrm{mg}$ of vitamin B6; $0.03 \mathrm{mg}$ of vitamin B12; $0.05 \mathrm{mg}$ of D-biotin; $1 \mathrm{mg}$ of folic acid; $80 \mathrm{mg}$ of Mn; $60 \mathrm{mg}$ of Zn; $60 \mathrm{mg}$ of Fe; 5 $\mathrm{mg} \mathrm{Cu} ; 0.2 \mathrm{mg}$ Co; $1 \mathrm{mg}$ of $\mathrm{l} ; 0.15 \mathrm{mg} \mathrm{Se}, 200 \mathrm{mg}$ choline chloride,

$2 \mathrm{~g} / \mathrm{kg} \mathrm{DM}$,

${ }^{3} \mathrm{ME}(\mathrm{Mcal} / \mathrm{kg} \mathrm{DM})=3019-10.66 \% \mathrm{CP}+37.33 \% \mathrm{AF}-26.90 \%$ Ash $-23.29 \% \mathrm{CF}$ calculated with the formula

${ }^{4}$ Nutrient of corn silage (dry matter, crude protein and ash) was determined by the methods described by AOAC (1998). Crude fiber was determined using Ankom cellulose analyzer, Van Soest et al., 1991; Kutlu, 2008)

Table 2 The effects of different amounts of corn silage and concentrated feed on body weight and body weight gain in geese 


\begin{tabular}{llllllll} 
Treatment & \multicolumn{3}{l}{ Live weight (g, week) } & \multicolumn{3}{c}{ Live weight gain (g, week) } \\
\hline & 19 & 23 & 27 & 30 & $19-22$ & $19-26$ & $19-30$ \\
\hline S00 & 3678.2 & 3998.4 & 4318.8 & 4452.2 & 320.2 & 640.6 & 774.0 \\
\hline S10 & 3646.4 & 3862.6 & 4179.0 & 4425.8 & 340.0 & 645.8 & 779.4 \\
\hline S20 & 3515.6 & 3679.8 & 3928.8 & 4019.0 & 164.2 & 413.2 & 503.4 \\
\hline S30 & 3560.2 & 3761.0 & 4094.0 & 4296.8 & 252.3 & 533.8 & 736.6 \\
\hline S40 & 3708.8 & 3871.8 & 4075.0 & 4200.0 & 228.3 & 457.5 & 584.0 \\
\hline SEM & 74.73 & 64.06 & 74.21 & 83.09 & 27.71 & 46.88 & 58.29 \\
\hline P value & 0.932 & 0.619 & 0.594 & 0.486 & 0.238 & 0.431 & 0.476
\end{tabular}

S00: Control group; S10: $10 \%$ corn silage + 90\% concentrate feed; S20: $20 \%$ corn silage + $80 \%$ concentrate feed; S30: $30 \%$ corn silage $+70 \%$ concentrate feed; S $40: 40 \%$ corn silage $+60 \%$ concentrate feed; SEM: standard error of mean.

Table 3 The effects of different amounts of corn silage and concentrated feed on feed consumption and feed efficiency in geese.

\begin{tabular}{lllllll} 
Treatment & \multicolumn{2}{l}{ Feed Intake $(\mathrm{g}$, week $)$} & \multicolumn{3}{c}{ Feed Conversion Ratio } \\
\hline & $19-22$ & $19-26$ & $19-30$ & $19-22$ & $19-26$ & $19-30$ \\
\hline S00 & 5201.5 & 10361.5 & 14925.1 & 17.74 & 19.17 & 24.37 \\
\hline S10 & 5235.2 & 10434.0 & 15736.8 & 19.61 & 16.68 & 26.81 \\
\hline S20 & 4687.1 & 9504.7 & 13940.9 & 35.24 & 24.74 & 30.36 \\
\hline S30 & 5459.6 & 11323.6 & 17006.4 & 23.11 & 22.75 & 23.63 \\
\hline S40 & 5855.2 & 11873.6 & 17304.2 & 40.05 & 39.32 & 38.53 \\
\hline SEM & 145.79 & 300.07 & 444.55 & 3.893 & 3.099 & 3.066 \\
\hline P value & 0.137 & 0.097 & 0.074 & 0.279 & 0.216 & 0.624
\end{tabular}

S00: Control group; S10: $10 \%$ corn silage + 90\% concentrate feed; S20: $20 \%$ corn silage $+80 \%$ concentrate feed; S30: $30 \%$ corn silage $+70 \%$ concentrate feed; $S 40: 40 \%$ corn silage $+60 \%$ concentrate feed; SEM: standard error of mean.

Table 4 Effects of different amounts of corn silage and concentrated feed on carcass characteristics, digestive system weight and edible visceral weights in geese 


\begin{tabular}{llllllllll} 
Treatment & $\begin{array}{l}\text { Slaughter } \\
\text { weight } \\
(\mathrm{g})\end{array}$ & $\begin{array}{l}\text { Dressing } \\
\text { percentage } \\
(\%)\end{array}$ & $\begin{array}{l}\text { Digestive } \\
\text { system } \\
\text { length(cm) }\end{array}$ & $\begin{array}{l}\text { DSL/LW } \\
(\%)^{\star}\end{array}$ & $\begin{array}{l}\text { Heart } \\
(\%)\end{array}$ & $\begin{array}{l}\text { Liver } \\
(\%)\end{array}$ & $\begin{array}{l}\text { Gizzard } \\
(\%)\end{array}$ & $\begin{array}{l}\text { AF/CW } \\
(\%)^{\star *}\end{array}$ & $\begin{array}{l}\text { AF/LW } \\
(\%)^{\star * *}\end{array}$ \\
\hline S00 & 4452.2 & 69.64 & 233.6 & 7.72 & $0.95 \mathrm{ab}$ & 1.43 & 3.02 & 8.15 & 5.70 \\
\hline S10 & 4425.8 & 67.07 & 229.0 & 9.18 & $1.02 \mathrm{ab}$ & 1.86 & 3.53 & 8.95 & 6.13 \\
\hline S20 & 4019.0 & 67.47 & 225.8 & 9.15 & $1.19 \mathrm{c}$ & 1.64 & 3.87 & 8.21 & 5.72 \\
\hline S30 & 4296.8 & 67.49 & 235.2 & 9.89 & $1.02 \mathrm{ab}$ & 1.86 & 4.27 & 8.58 & 5.74 \\
\hline S40 & 4200.0 & 68.34 & 226.8 & 8.80 & $1.03 \mathrm{ab}$ & 1.58 & 3.59 & 6.68 & 4.54 \\
\hline SEM & 83.09 & 7.776 & 2.66 & 0.252 & 0.024 & 0.057 & 0.148 & 0.410 & 0.361 \\
\hline Pvalue & 0.486 & 0.989 & 0.777 & 0.077 & $\mathbf{0 . 0 2 2}$ & 0.056 & 0.086 & 0.499 & 0.729
\end{tabular}

* DSL/LW (Digestive system length /Live weight x 100) ** AF/CW (Abdominal fat/Carcass weight x 100) *** AF/LW (Abdominal fat / Live weight $x$ 100),

S00: Control group; S10: $10 \%$ corn silage + 90\% concentrate feed; S20: $20 \%$ corn silage $+80 \%$ concentrate feed; S30: $30 \%$ corn silage $+70 \%$ concentrate feed; S40: $40 \%$ corn silage $+60 \%$ concentrate feed; SEM: standard error of mean.

Table 5 The effect of different amounts of corn silage and concentrated feed on the nutrient content of goose breast meat

\begin{tabular}{lllll} 
Treatment & $\begin{array}{l}\text { Dry matter } \\
(\%)\end{array}$ & $\begin{array}{l}\text { Protein } \\
(\%)\end{array}$ & $\begin{array}{l}\text { Fat } \\
(\%)\end{array}$ & $\begin{array}{l}\text { Ash } \\
(\%)\end{array}$ \\
\hline S00 & 28.14 & 23.64 & $3.60 \mathrm{ab}$ & 0.90 \\
\hline S10 & 29.63 & 24.10 & $4.50 \mathrm{a}$ & 1.03 \\
\hline S20 & 29.64 & 23.65 & $4.84 \mathrm{a}$ & 1.16 \\
\hline S30 & 28.15 & 24.62 & $2.40 \mathrm{~b}$ & 1.13 \\
\hline S40 & 29.68 & 23.84 & $4.64 \mathrm{a}$ & 1.20 \\
\hline SEM & 0.268 & 0.145 & 0.311 & 0.054 \\
\hline P value & 0.075 & 0.153 & $\mathbf{0 . 0 4 1}$ & 0.435
\end{tabular}

S00: Control group; S10: $10 \%$ corn silage + 90\% concentrate feed; S20: $20 \%$ corn silage +\% concentrate feed; S30: $30 \%$ corn silage $+70 \%$ concentrate feed; S40: $40 \%$ corn silage $+60 \%$ concentrate feed; SEM: standard error of mean.

Table 6 Effects of different amounts of corn silage and concentrated feed on $\mathrm{pH}$ and color characteristics of breast and thigh meat of geese 


\begin{tabular}{lllllllll} 
Treatment & \multicolumn{2}{l}{ Breast meat } & \multicolumn{7}{l}{ thigh meat } \\
& $L^{*}$ & $\mathrm{a}$ & $\mathrm{b}$ & $\mathrm{pH}$ & $\mathrm{L}^{*}$ & $\mathrm{a}$ & $\mathrm{b}$ & $\mathrm{pH}$ \\
\hline S00 & $72.81 \mathrm{a}$ & 3.53 & 7.70 & 6.85 & $70.47 \mathrm{a}$ & 4.23 & 1.59 & 7.17 \\
\hline S10 & $72.70 \mathrm{a}$ & 3.77 & 6.74 & 6.82 & $70.91 \mathrm{a}$ & 2.83 & 2.73 & 7.09 \\
\hline S20 & $70.03 \mathrm{~b}$ & 3.90 & 7.47 & 6.91 & $69.98 \mathrm{a}$ & 3.22 & 2.50 & 7.25 \\
\hline S30 & $70.16 \mathrm{~b}$ & 3.99 & 7.25 & 6.79 & $68.92 \mathrm{a}$ & 3.75 & 4.05 & 7.19 \\
\hline S40 & $68.41 \mathrm{c}$ & 3.92 & 7.72 & 6.78 & $65.79 \mathrm{~b}$ & 4.97 & 3.57 & 7.15 \\
\hline SEM & 0.41 & 0.21 & 0.26 & 0.04 & 0.51 & 0.26 & 0.45 & 0.03 \\
\hline P value & $\mathbf{0 . 0 0 0}$ & 0.973 & 0.788 & 0.839 & $\mathbf{0 . 0 0 2}$ & 0.065 & 0.482 & 0.507
\end{tabular}

S00: Control group; S10: $10 \%$ corn silage + 90\% concentrate feed; S20: $20 \%$ corn silage $+80 \%$ concentrate feed; S30: $30 \%$ corn silage $+70 \%$ concentrate feed; S40: $40 \%$ corn silage $+60 \%$ concentrate feed; SEM: standard error of mean. $\mathrm{L}$ *: Lightness; a: Redness; b: Yellowness.

Table 7 Effects of different amounts of corn silage and concentrated feed on the sensory properties of meat in Turkish native goose (Mean, minimum and maximum values)

\begin{tabular}{llllllll} 
Treatment & Appearance & Flavour & Hardness & Tenderness & Juijeness & Chewiness & $\begin{array}{l}\text { Overall } \\
\text { impression }\end{array}$ \\
\hline S00 & $7.1(7: 5-8)$ & $\begin{array}{l}7.1(7: 4- \\
9)\end{array}$ & $6.9(7: 5-8)$ & $6.9(8: 4-9)$ & $6.3(7: 3-9)$ & $7.2(8: 3-9)$ & $7.3(8: 5-9)$ \\
\hline S10 & $7.4(8: 5-9)$ & $\begin{array}{l}6.9(7: 4- \\
9\end{array}$ & $6.7(7: 4-8)$ & $6.6(7: 3-9)$ & $6.3(7: 3-9)$ & $7.2(8: 4-9)$ & $7.2(8: 5-9)$ \\
\hline S20 & $7.4(8: 5-9)$ & $\begin{array}{l}7.2(8: 4- \\
9\end{array}$ & $7.4(8: 5-9)$ & $7.4(8: 4-9)$ & $6.9(7: 3-9)$ & $7.8(8: 5-9)$ & $7.5(8: 5-9)$ \\
\hline S30 & $7.3(8: 5-9)$ & $\begin{array}{l}7.2(8: 3- \\
9)\end{array}$ & $7.2(8: 4-9)$ & $7.2(8: 4-9)$ & $6.8(7: 4-9)$ & $7.3(8: 5-9)$ & $7.4(8: 4-9)$ \\
\hline S40 & $7.4(7: 5-9)$ & $\begin{array}{l}6.9(7: 4- \\
9\end{array}$ & $7.1(7: 5-9)$ & $6.9(7: 3-9)$ & $6.6(7: 3-9)$ & $7.2(8: 5-9)$ & $7.3(8: 5-9)$ \\
\hline SEM & 0.11 & 0.14 & 0.14 & 0.16 & 0.18 & 0.14 & 0.13
\end{tabular}

S00: Control group; S10: $10 \%$ corn silage + 90\% concentrate feed; S20: $20 \%$ corn silage + 80\% concentrate feed; S30: $30 \%$ corn silage $+70 \%$ concentrate feed; $S 40: 40 \%$ corn silage $+60 \%$ concentrate feed; SEM: standard error of mean.

\section{Figures}




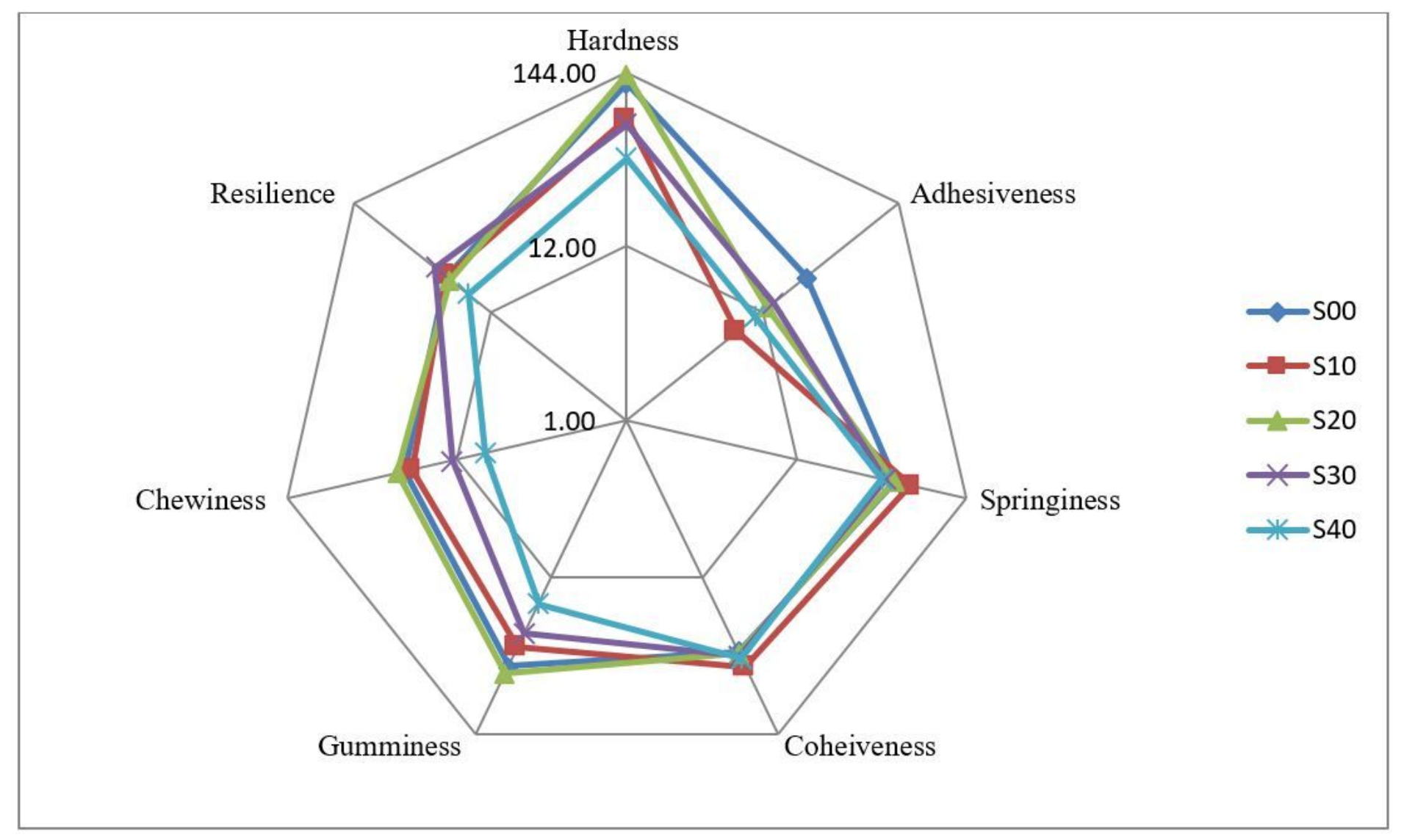

\section{Figure 1}

The effect of different amounts of corn silage and concentrated feed on the texture profile analysis of Turkish goose variety

S00: Control group; S10: $10 \%$ corn silage + 90\% concentrate feed; S20: $20 \%$ corn silage $+80 \%$ concentrate feed; S30: $30 \%$ corn silage $+70 \%$ concentrate feed; S $40: 40 \%$ corn silage $+60 \%$ concentrate feed; SEM: standard error of mean. 